\title{
1 Microbiological quality of ready-to-eat pickled fish products
}

\section{Short title: Bacteriological quality of RTE products}

\section{Abstract}

4 The bacteriological quality of 18 commercially available ready-to-eat fish products containing

5 Engraulidae was evaluated through application of the corresponding ISO procedures for total

6 mesophilic aerobic microbial counts, detection and enumeration of Enterobacteriaceae and

7 detection of Staphylococcus spp. All isolates were identified to the species level using two

8 different biochemical methods as the $\mathrm{API}^{\circledR}$ test and the Biolog ${ }^{\circledR}$ identification system. The

9 most commonly occurring contaminants found were Enterobacteriaceae like Citrobacter freundii and other Citrobacter species, Enterobacter cloacae, Cronobacter sakazakii, Hafnia products were considered not apt for consumption.

\section{Keywords} opportunistic pathogens

\section{Introduction}

In modern intensive everyday life the availability, quality and safety of ready-to-eat (RTE) foods has been increasingly gaining importance. Novel and attractive preparations are constantly provided to the market and restaurant sector, products which require detailed study 
(Commission Regulation No 2073/2005 and its modification No 1441/2007) "ready-to-eat" food means food intended by the producer or the manufacturer for direct human consumption without the need for cooking or other processing effective to eliminate or reduce to an acceptable level the microorganisms of concern. RTE food safety control implies the application of internationally validated analytical protocols (corresponding ISO procedures) for detection and quantification of indicator and pathogenic microorganisms as according to the microbiological criteria fixed in the current national and European legislations (Commission Regulations No 2073/2005 and No 1441/2007). Most commonly adopted indicators include coliforms, Enterobacteriaceae, total viable counts, though this criterion is rather general and gives no detailed information on the identity of the microflora present, coagulase positive Staphylococci and pathogenic microorganisms like Salmonella and Listeria monocytogenes. In the case of RTE products elaborated with fish and/or seafood the only existing legislative criteria from a microbiological point of view are fixed for cooked crustaceans and molluscan shellfish. For products which have undergone enzyme maturation treatment in brine, manufactured from fish species associated with a high amount of histidine, limits are also fixed for the amounts of histamine present in the final product. However, the safety of all RTE foods may be affected by the microbiological quality of the starting materials as well as by the handling, processing, transportation and storage conditions of the finished product before its actual use by the consumer (Angelidis et al. 2006).

In the international scientific literature several studies exist on the problematic microbiological quality and characteristics of traditional RTE foods from different countries (Yeboah-Manu et al. 2010; Haryani et al. 2008; Angelidis et al. 2006; Thapa et al. 2006; Fang et al. 2003). Nine bacterial pathogens were isolated from various RTEs distributed at the University of Ghana campus (Yeboah-Manu et al. 2010) namely Escherichia coli (E. coli), Klebsiella pneumoniae, Streptococcus sp., Enterobacter cloacae (E. cloacae), Bacillus sp., 
Pseudomonas aeruginosa, Staphilococcus aureus (S. aureus), Enterococcus faecalis and

Proteus sp. Moreover, high occurrence of E. cloacae (7 strains with proven antibiotic resistance) in several typical Malaysian RTE products sold in the street has been reported (Haryani et al. 2008). In a broad study of commercially available traditional Greek RTE foods $3.4 \%$ of the products were unacceptable for consumption due to exceeding pathogen levels of S. aureus and E. coli while a considerable percentage of samples was found to contain high concentrations of contaminating microflora (Angelidis et al. 2006). In a similar research carried out with a wide number of commercial RTEs from central Taiwan incidences as high as $7.9 \%$ for E. coli, $49.8 \%$ for Bacillus cereus and $17.9 \%$ for S. aureus were detected (Fang et al. 2003). Cronobacter (Enterobacter sakazakii), an opportunistic human pathogen associated mainly with infant infections but also in some cases causative agent of adult infection outbreaks (Lai 2001; Ray et al. 2007; See et al. 2007; Gosney 2008) has been found in different categories of Swiss ready-to-eat foods other than infant formula (Baumgartner $e t$ al. 2009).

One of the most typical Spanish RTE fish products, the anchovies in brine or in oil, belongs to the group of the semi-preserved RTE foods, obtained without any heating process to stabilize the end product. These are prepared from fresh Engraulis sp. by salting and ripening during prolonged periods of time, usually for more than 3 months. Further on, the ripened fish is desalted, filleted and immersed in brine or oil, with final presentation at the market in glass jars or cans. This end product must be kept chilled and even if manufacturer's storage instructions are respected, proteolytic and other quality changes may occur before consumption as previously demonstrated (Veciana-Nogués et al. 1997; Rodriguez-Jerez et al. 1994). The desalting and filleting procedures prior to packaging increase the risk of secondary bacterial contamination of the end product. To our knowledge there are not many works 
72 published on the diversity of enterobacteria and their evolution upon refrigerated storage in this type of marketed Spanish traditional RTE.

The aim of our study was to investigate the microbiological quality and the evolution of the enterobacterial content upon storage of different Engraulis based ready-to-eat products from the Spanish market. The final objective was to evaluate the existing risks for the consumer's health in the selected products thus providing important information to the manufacturers of this type of fish foods since currently there are no fixed legal limits for microbiological indicators. European legislation in vigour (Commission Regulations No 2073/2005 and No 1441/2007) allows manufacturers to establish their proper control limits depending on the specific production processes and in function of their Hazard Analysis and Critical Control Points (HACCP) programmes.

\section{Materials and Methods}

\subsection{Food samples}

Eighteen samples of ready-to-eat foods prepared with Engraulidae were purchased in Spanish retailers and supermarkets between December 2009 and April 2010 (3 products per batch from each commercial brand). These comprised 11 samples of anchovies in olive oil, 2 samples of anchovies in sunflower oil and 3 sample of anchovies in another type of vegetable oil, one sample of snacks of anchovies with onion, red peppers and olives (presented immersed in oil) and one sample of snacks of Engraulis with onion, red peppers and olives (also immersed in vegetable oil). All samples were produced by 14 different manufacturers, some wearing brands well known to the Spanish consumer.

\subsection{Bacteriological analysis of ready-to-eat foods}


The analysis of the commercial samples was done according to the following ISO procedures: ISO 4833:2003, ISO 21528-1:2004 and ISO 6888-3:2003, taking into account the ISO 7218:2007. The enrichment step for the initial detection and isolation of Enterobacteriaceae in all samples analyzed was done in tubes with $9 \mathrm{ml}$ Buffered Peptone Water (Biokar Diagnostics, Beauvais, France) inoculated with $1 \mathrm{~g}$ from the respective sample. After $24 \mathrm{~h}$ incubation at $37^{\circ} \mathrm{C} 1 \mathrm{ml}$ from each of these tubes was passed to a tube with $10 \mathrm{ml}$ E.E. Broth (Oxoid Ltd., Basingstoke, UK). These tubes were further incubated for $24 \mathrm{~h}$ at $37^{\circ} \mathrm{C}$ and then used for the inoculation of three plates per sample of Violet Red Bile Glucose Agar (VRBG) (Cultimed, Panreac, Castellar del Valles, Spain). Colonies with different morphologies observed on VRBG were then isolated separately by passing to plates with Nutrient Agar at 2\% (Biokar Diagnostics, Beauvais, France) containing $5 \mathrm{~g} / \mathrm{l} \mathrm{NaCl}$. A biochemical confirmation was done of the ability of each pure isolate to ferment glucose in tubes with 10 $\mathrm{ml}$ of Dextrose Tryptone Yeast Bromocresol Agar (Glucose agar) (Laboratorios Microkit, Madrid, Spain). The change of the colour to yellow at the end of the incubation time (24h \pm 2 at $37^{\circ} \mathrm{C}$ ) was considered as positive result. The oxidase reaction of each isolate was also verified by applying a drop from the Oxydase reagent (BioMerieux SA, Marcy l'Etoile, France) on a single colony material as according to the instructions of the reagent's producer.

\subsubsection{Definition of Total Viable Counts}

For the enumeration of the TVCs $5 \mathrm{~g}$ per product were weighed from the corresponding sample in stomacher bags Fbag-03 (AES Chemunex SA, Barcelona, Spain) in aseptic conditions. The samples were then diluted with $45 \mathrm{ml}$ of sterile Buffered Peptone Water (BPW) (Biokar Diagnostics, Beauvais, France) and homogenized during $30 \mathrm{sec}$. in a Laboratory Blender Stomacher 400 (Seward Ltd., West Sussex, UK). Serial ten-fold dilutions up to $10^{-7}$ were prepared per sample in tubes with $9 \mathrm{ml} \mathrm{BPW}$. Two Petri dishes with agar were inoculated from each dilution. In the case of aerobic mesophiles the agar medium applied was 
120 Plate Count Agar (PCA) (Biokar Diagnostics, Beauvais, France), with a second layer of

121 Bacteriological agar type $\mathrm{E}$ at $18 \mathrm{~g} / \mathrm{l}$ (Biokar Diagnostics, Beauvais, France). For the 122 enumeration of the anaerobic mesophilic microflora agar Schaedler (Biokar Diagnostics, 123 Beauvais, France) with defibrinated sheep blood at $5 \%$ (E\&O Laboratories Ltd., UK) was 124 used. Aerobic TVC were cultivated for $72 \mathrm{~h}$ at $30 \pm 1{ }^{\circ} \mathrm{C}$ and anaerobic TVC - at $37 \pm 1{ }^{\circ} \mathrm{C}$ 125 for $72 \mathrm{~h}$ at anaerobic conditions, assured by the GENbag anaer system (BioMerieux SA, 126 Marcy l'Etoile, France). The different morphologies obtained on the TVC agar plates were 127 further isolated on Tryptone Soy Agar (TSA) (Biokar Diagnostics, Beauvais, France) and 128 Nutrient Agar at $2 \%$ (Biokar Diagnostics, Beauvais, France) for Gram staining and 129 identification.

\section{2.2.2. Definition of the Total Enterobacterial Counts}

131 For the enumeration of the total enterobacterial counts the samples from the same batch and

132 brand were opened, mixed and $25 \mathrm{~g}$ per product were weighted in TEMPO ${ }^{\circledR}$ bags 133 (BioMerieux SA, Marcy l'Etoile, France) in aseptic conditions. These were diluted with 225 $134 \mathrm{ml}$ of sterile Tryptone-Salt broth (Biokar Diagnostics, Beauvais, France) and homogenized 135 during $30 \mathrm{sec}$. in our Laboratory Blender Stomacher 400. Further on this material was used 136 for the inoculation of TEMPO ${ }^{\circledR} \mathrm{EB}$ cards (BioMerieux SA, Marcy l'Etoile, France) in the 137 TEMPO $^{\circledR}$ preparation station as according to the manufacturer's instructions. The cards were 138 incubated during $24 \mathrm{~h}$ at $35 \pm 1{ }^{\circ} \mathrm{C}$ in an incubator and then results were read and interpreted 139 with the TEMPO $^{\circledR}$ Reader station and associated software. This method represents a 140 miniaturized MPN assay.

\subsection{Identification of the isolates}

142 Gram staining was done for all pure enterobacterial and mesophillic isolates. Catalase 143 reaction was tested for the TVC isolates on single colony material by treatment with a 


\subsubsection{Identification by $A P I^{\circledR}$ tests}

Fresh $(24 \mathrm{~h})$ colonies of all enterobacterial isolates were homogenized in sterile distilled water and inoculated into API 20E galleries (BioMerieux SA, Marcy l'Etoile, France) following the instructions of the manufacturer. For some TVC isolates identification was done with the API 20A (Anaerobes) and API 50CHB (Bacillus) galleries, where applicable, as in accordance with the list of genera/species included in the identification range of the corresponding type of gallery. Staphylococcal isolates were identified by the API Staph test. Results were expressed in percentages of probability for the identification as according to the ApiWeb software.

\subsubsection{Biolog ${ }^{\circledR}$ Identification}

In parallel, the Biolog ${ }^{\circledR}$ MicroStation system and related software (Biolog, USA) were used for the identification of all enterobacterial and TVC isolates obtained. For the purpose the pure isolates were inoculated on TSA plates prior to Biolog ${ }^{\circledR}$ analysis and incubated at the corresponding conditions for each microbial group. Anaerobiosis was applied in the case of the anaerobic TVC isolates using the GENbag anaer system. The cultures were consequently resuspended in tubes with $10 \mathrm{ml}$ of GN/GP-IF inoculation fluid (Biolog, USA) using the Biolog $^{\circledR}$ turbidity standards and with addition of Biolog ${ }^{\circledR}$ sodium thioglycolate reagent as according to the instructions of the manufacturer. These tubes were used for the inoculation of Biolog ${ }^{\circledR}$ GN2 plates in the case of Gram negative isolates and Biolog ${ }^{\circledR}$ GP2 plates in the case of Gram positive isolates. All plates were inoculated during $24 \mathrm{~h}$ at the cultivation temperatures required $\left(37 \pm 1{ }^{\circ} \mathrm{C}\right.$ for Enterobacteria and $30{ }^{\circ} \mathrm{C}$ for mesophiles) and then results were read in the Biolog ${ }^{\circledR}$ MicroStation plate reader. Interpretation of results was done with the MicroLog3 4.20.04 software and these were expressed in percentages of probability 


\subsection{Shelf life study}

Thirteen commercial products of anchovies in oil were selected at random for the shelf life study in refrigeration, at $4-8^{\circ} \mathrm{C}$, storage conditions adequate for this type of semi-preserves (products stabilized for a limited period by appropriate treatment and sealed in containers,

\subsection{Definition of the histamine content}

Histamine content was measured by HPLC reverse phase chromatography as according to Vieites and colleagues (Ben-Gigirey et al. 1999). $4 \mathrm{~g}$ of homogenized sample were mixed with $20 \mathrm{ml}$ perchloric acid $0.4 \mathrm{M}$, centrifuged for 20 minutes at $4000 \mathrm{rpm}$, and filtered. 1 $\mathrm{ml}$ of the extracted sample was derivatized by adding $200 \mu \mathrm{l} \mathrm{NaOH} 2 \mathrm{~N}, 300 \mu \mathrm{l}$ sodium bicarbonate (saturated solution) and $2 \mathrm{ml}$ dansyl chloride. Tubes were incubated for 45 minutes at $46{ }^{\circ} \mathrm{C}$. Then dansyl chloride residues were removed with $100 \mu \mathrm{l}$ ammonia, centrifuged 5 minutes at $4000 \mathrm{rpm}$, and filtered. Derivatized samples were injected in an HPLC/PDA system (Waters Corporation, MA, USA), using a Nucleosil C18 $5 \mu \mathrm{m}$ reverse phase column and monitored at $\lambda=254 \mathrm{mn}$. Histamine dihydrochloride, mínimum $99 \%$ purity, was purchased by SIGMA-ALDRICH and was used as standard. The detection 


\subsection{Bacteriological analysis of ready-to-eat foods}

\section{Results}

Table 1 presents all food products examined as according to their covering sauce along with the total enterobacterial counts and the corresponding identification of the isolates obtained on selective media (E.E. broth, VRBG) after enrichment. Seven out of the 18 products (approx. $39 \%$ ) did not contain any Enterobacteria, among these four products of anchovies in olive oil, one product of anchovies in vegetable oil and two products of anchovy/ Engraulis spp. snacks. From the rest of the products a total of 30 different Gram-negative, oxidase negative isolates were obtained. Although in most positive samples enterobacteria were present in amounts below the limit of detection of the TEMPO ${ }^{\circledR}$ method $(10 \mathrm{cfu} / \mathrm{g}), 3$ samples showed significant enterobacterial counts $(640,33$ and $21 \mathrm{cfu} / \mathrm{g})$. The sample with highest enterobacterial counts showed highest number of different isolates. The prevailing genera among all isolates were Enterobacter (represented by 8 isolates), Citrobacter (7 isolates), Proteus (3 isolates), Cronobacter (Enterobacter sakazakii) (3 isolates), Hafnia (2 isolates) and Escherichia (2 isolates, among which one identified as E. coli O157:H7). Klebsiella, Serratia, Raoultella and Pantoea were represented by single species each. Citrobacter 
216 positive or negative. In contrast to enterobacterial counts TVC were present in all the

217 samples; however, in 5 products (all anchovies in olive oil, approx. $28 \%$ of the total) only

218 lactic acid bacteria (LAB) were found, namely Pediococcus pentosaceus, a species renowned

219 for its probiotic properties (Osmanagaoglu et al. 2010; Semjonovs \& Zikmanis 2008). In the

rest of the products the contaminating (non-LAB) microflora was more important in quantities. The mesophillic aerobic isolates included several representatives of the coagulase negative Staphylococci (among which Staphylococcus xylosus), Cellulomonas, Rhodococcus, Bacillus and Corynebacterium. Among the anaerobic isolates Desulfomonile tiedjei and Fusobacterium mortiferum were detected. Certain Actinomyces isolates were also found in three of the products as identified by both API and Biolog.

\subsection{Comparison of the methods for identification of the isolates}

Both methods used by us for the identification of the isolates were based on biochemical characterization of each microorganism's carbohydrate metabolism. The Biolog system implies testing for 95 different carbohydrates while the API system is in general more limited in the number of substrates analysed, depending on outreach of each gallery. Therefore, the API system has a more limited database for comparison and certain species are excluded from possible identification as stated in the instruction manuals of the corresponding galleries. We have tried to apply both systems for each isolate, whenever available, in order to reach better identification. In most of the cases the results obtained by the two methods were in good concordance, however, certain discrepancies existed for some of the enterobacterial isolates. In such cases the method providing higher identification probability was selected and included as final identification result in Tables 1 and 2. The identification probabilities given by the Biolog system were very often expressed in similarity index values since no sufficient growth was reached during the maximum incubation period advised by the manufacturer ( 24 


\subsection{Shelf life study}

243

The shelf life study concerning microbiological parameters was realized on thirteen products designated by numbers $4-16$ in Tables 1 and 2 . The initial enterobacterial counts and total number of enterobacterial isolates at time 0 were highest, followed by a prominent decrease after 3 months of storage. At the experimental point of 6 months no enterobacterial counts were found in any of the tested products and only two isolates were obtained after enrichment from the product with highest initial counts $(640 \mathrm{cfu} / \mathrm{g})$ (Fig. 1). No enterobacterial counts /isolates were obtained after 9 months of storage. The most persistent species at refrigeration conditions belonged to the genera Enterobacter and Pantoea (data not shown). Cronobacter (Enterobacter sakazakii) had generally poor viability under the selected conditions. The same reduction in counts was not observed for the TVC. The number of TVC isolates increased for most samples with the increase of the storage period (Fig. 2). The catalase negative staphylococcal isolates (Staph. lentus, Staph. warneri, Staph. saprophyticus, Staph. arlettae, etc.) were the most resistant group at the selected storage conditions. The histamine quantities detected (two values below the detection limit of the method of $10 \mathrm{mg} / \mathrm{kg}$ and one value of 84 $\pm 22 \mathrm{mg} / \mathrm{kg}$ ) in the samples analyzed were below the officially allowed limit for histamine $(200 \mathrm{mg} / \mathrm{kg})$ in products manufactured from fish species associated with high histidine amounts (Commission Regulations No 2073/2005 and No1441/2007).

\section{Discussion}

In this report 18 RTE food products were included, selected and acquired after a preliminary market study. Semi-preserves elaborated with Engraulidae and presented in various types of 
264 covering sauces are highly appreciated by local and international consumers; therefore, their

265

systematic safety control is of great relevance to avoid public health risks. After application of the established ISO procedures for the detection and quantification of indicator and pathogenic microorganisms or alternative validated methods (TEMPO), presence of certain opportunistic or obligate bacterial pathogens, mainly belonging to the Enterobacteriaceae family, was confirmed in $61 \%$ of the foods sampled. Three of the products (17\%) could be considered unsafe for consumption due to their high enterobacterial counts. Thirty different enterobacterial species were isolated from all products analyzed.

Enterobacteriaceae are generally accepted as the primary cause of food spoilage and histamine development in different food products. Species like Citrobacter freundii, found to be one of the predominant enterobacterial isolates in the current research work, together with Morganella morganii, Proteus spp., Enterobacter spp., Klebsiella pneumoniae, Escherichia spp., Hafnia alvei, Raoultella spp. and Serratia spp. have previously been reported as biogenic amine producers in various foods - tuna sandwiches (Kung et al. 2009), packaged and processed meat (Durlu - Özkaya et al. 2001), seafood (Kim et al. 2003), salted mackerel (Tsai et al. 2005), etc., causing indigestion, intoxications and food allergies. Morganella, Citrobacter, Proteus spp., Klebsiella pneumoniae and Hafnia alvei have been known for their important histamine production while Enterobacter amnigenus and Enterobacter cloacae have been shown to produce particularly high amounts of putrescine (Lavizzari et al. 2010). Although we have not isolated any Morganella morganii or Klebsiella pneumoniae species from Engraulis spp. containing RTE foods we have identified several isolates with known histidine decarboxilase activities as Proteus penneri, Proteus mirabilis, Proteus vulgaris, Pantoea spp., Raoultella planticola/ ornithinolytica, Raoultella terrigena and Serratia ficaria. The presence of these microorganisms could suppose certain degree of filet softening, proteolysis, histamine accumulation and spoilage during the storage of the sampled foods. 


\section{Microbiological quality of ready-to-eat pickled fish products}

\section{Short title: Bacteriological quality of RTE products}

\section{Abstract}

4 The bacteriological quality of 18 commercially available ready-to-eat fish products containing

5 Engraulidae was evaluated through application of the corresponding ISO procedures for total

6 mesophilic aerobic microbial counts, detection and enumeration of Enterobacteriaceae and

7 detection of Staphylococcus spp. All isolates were identified to the species level using two

8 different biochemical methods as the $\mathrm{API}^{\circledR}$ test and the Biolog ${ }^{\circledR}$ identification system. The

9 most commonly occurring contaminants found were Enterobacteriaceae like Citrobacter freundii and other Citrobacter species, Enterobacter cloacae, Cronobacter sakazakii, Hafnia products were considered not apt for consumption.

\section{Keywords} opportunistic pathogens

\section{Introduction}

In modern intensive everyday life the availability, quality and safety of ready-to-eat (RTE) foods has been increasingly gaining importance. Novel and attractive preparations are constantly provided to the market and restaurant sector, products which require detailed study 
(Commission Regulation No 2073/2005 and its modification No 1441/2007) "ready-to-eat" food means food intended by the producer or the manufacturer for direct human consumption without the need for cooking or other processing effective to eliminate or reduce to an acceptable level the microorganisms of concern. RTE food safety control implies the application of internationally validated analytical protocols (corresponding ISO procedures) for detection and quantification of indicator and pathogenic microorganisms as according to the microbiological criteria fixed in the current national and European legislations (Commission Regulations No 2073/2005 and No 1441/2007). Most commonly adopted indicators include coliforms, Enterobacteriaceae, total viable counts, though this criterion is rather general and gives no detailed information on the identity of the microflora present, coagulase positive Staphylococci and pathogenic microorganisms like Salmonella and Listeria monocytogenes. In the case of RTE products elaborated with fish and/or seafood the only existing legislative criteria from a microbiological point of view are fixed for cooked crustaceans and molluscan shellfish. For products which have undergone enzyme maturation treatment in brine, manufactured from fish species associated with a high amount of histidine, limits are also fixed for the amounts of histamine present in the final product. However, the safety of all RTE foods may be affected by the microbiological quality of the starting materials as well as by the handling, processing, transportation and storage conditions of the finished product before its actual use by the consumer (Angelidis et al. 2006).

In the international scientific literature several studies exist on the problematic microbiological quality and characteristics of traditional RTE foods from different countries (Yeboah-Manu et al. 2010; Haryani et al. 2008; Angelidis et al. 2006; Thapa et al. 2006; Fang et al. 2003). Nine bacterial pathogens were isolated from various RTEs distributed at the University of Ghana campus (Yeboah-Manu et al. 2010) namely Escherichia coli (E. coli), Klebsiella pneumoniae, Streptococcus sp., Enterobacter cloacae (E. cloacae), Bacillus sp., 
Pseudomonas aeruginosa, Staphilococcus aureus (S. aureus), Enterococcus faecalis and

Proteus sp. Moreover, high occurrence of E. cloacae (7 strains with proven antibiotic resistance) in several typical Malaysian RTE products sold in the street has been reported (Haryani et al. 2008). In a broad study of commercially available traditional Greek RTE foods $3.4 \%$ of the products were unacceptable for consumption due to exceeding pathogen levels of S. aureus and E. coli while a considerable percentage of samples was found to contain high concentrations of contaminating microflora (Angelidis et al. 2006). In a similar research carried out with a wide number of commercial RTEs from central Taiwan incidences as high as $7.9 \%$ for E. coli, $49.8 \%$ for Bacillus cereus and $17.9 \%$ for S. aureus were detected (Fang et al. 2003). Cronobacter (Enterobacter sakazakii), an opportunistic human pathogen associated mainly with infant infections but also in some cases causative agent of adult infection outbreaks (Lai 2001; Ray et al. 2007; See et al. 2007; Gosney 2008) has been found in different categories of Swiss ready-to-eat foods other than infant formula (Baumgartner $e t$ al. 2009).

One of the most typical Spanish RTE fish products, the anchovies in brine or in oil, belongs to the group of the semi-preserved RTE foods, obtained without any heating process to stabilize the end product. These are prepared from fresh Engraulis sp. by salting and ripening during prolonged periods of time, usually for more than 3 months. Further on, the ripened fish is desalted, filleted and immersed in brine or oil, with final presentation at the market in glass jars or cans. This end product must be kept chilled and even if manufacturer's storage instructions are respected, proteolytic and other quality changes may occur before consumption as previously demonstrated (Veciana-Nogués et al. 1997; Rodriguez-Jerez et al. 1994). The desalting and filleting procedures prior to packaging increase the risk of secondary bacterial contamination of the end product. To our knowledge there are not many works 
72 published on the diversity of enterobacteria and their evolution upon refrigerated storage in this type of marketed Spanish traditional RTE.

The aim of our study was to investigate the microbiological quality and the evolution of the enterobacterial content upon storage of different Engraulis based ready-to-eat products from the Spanish market. The final objective was to evaluate the existing risks for the consumer's health in the selected products thus providing important information to the manufacturers of this type of fish foods since currently there are no fixed legal limits for microbiological indicators. European legislation in vigour (Commission Regulations No 2073/2005 and No 1441/2007) allows manufacturers to establish their proper control limits depending on the specific production processes and in function of their Hazard Analysis and Critical Control Points (HACCP) programmes.

\section{Materials and Methods}

\subsection{Food samples}

Eighteen samples of ready-to-eat foods prepared with Engraulidae were purchased in Spanish retailers and supermarkets between December 2009 and April 2010 (3 products per batch from each commercial brand). These comprised 11 samples of anchovies in olive oil, 2 samples of anchovies in sunflower oil and 3 sample of anchovies in another type of vegetable oil, one sample of snacks of anchovies with onion, red peppers and olives (presented immersed in oil) and one sample of snacks of Engraulis with onion, red peppers and olives (also immersed in vegetable oil). All samples were produced by 14 different manufacturers, some wearing brands well known to the Spanish consumer.

\subsection{Bacteriological analysis of ready-to-eat foods}


The analysis of the commercial samples was done according to the following ISO procedures: ISO 4833:2003, ISO 21528-1:2004 and ISO 6888-3:2003, taking into account the ISO 7218:2007. The enrichment step for the initial detection and isolation of Enterobacteriaceae in all samples analyzed was done in tubes with $9 \mathrm{ml}$ Buffered Peptone Water (Biokar Diagnostics, Beauvais, France) inoculated with $1 \mathrm{~g}$ from the respective sample. After $24 \mathrm{~h}$ incubation at $37^{\circ} \mathrm{C} 1 \mathrm{ml}$ from each of these tubes was passed to a tube with $10 \mathrm{ml}$ E.E. Broth (Oxoid Ltd., Basingstoke, UK). These tubes were further incubated for $24 \mathrm{~h}$ at $37^{\circ} \mathrm{C}$ and then used for the inoculation of three plates per sample of Violet Red Bile Glucose Agar (VRBG) (Cultimed, Panreac, Castellar del Valles, Spain). Colonies with different morphologies observed on VRBG were then isolated separately by passing to plates with Nutrient Agar at 2\% (Biokar Diagnostics, Beauvais, France) containing $5 \mathrm{~g} / \mathrm{l} \mathrm{NaCl}$. A biochemical confirmation was done of the ability of each pure isolate to ferment glucose in tubes with 10 $\mathrm{ml}$ of Dextrose Tryptone Yeast Bromocresol Agar (Glucose agar) (Laboratorios Microkit, Madrid, Spain). The change of the colour to yellow at the end of the incubation time (24h \pm 2 at $37^{\circ} \mathrm{C}$ ) was considered as positive result. The oxidase reaction of each isolate was also verified by applying a drop from the Oxydase reagent (BioMerieux SA, Marcy l'Etoile, France) on a single colony material as according to the instructions of the reagent's producer.

\subsubsection{Definition of Total Viable Counts}

For the enumeration of the TVCs $5 \mathrm{~g}$ per product were weighed from the corresponding sample in stomacher bags Fbag-03 (AES Chemunex SA, Barcelona, Spain) in aseptic conditions. The samples were then diluted with $45 \mathrm{ml}$ of sterile Buffered Peptone Water (BPW) (Biokar Diagnostics, Beauvais, France) and homogenized during $30 \mathrm{sec}$. in a Laboratory Blender Stomacher 400 (Seward Ltd., West Sussex, UK). Serial ten-fold dilutions up to $10^{-7}$ were prepared per sample in tubes with $9 \mathrm{ml} \mathrm{BPW}$. Two Petri dishes with agar were inoculated from each dilution. In the case of aerobic mesophiles the agar medium applied was 
120 Plate Count Agar (PCA) (Biokar Diagnostics, Beauvais, France), with a second layer of

121 Bacteriological agar type $\mathrm{E}$ at $18 \mathrm{~g} / \mathrm{l}$ (Biokar Diagnostics, Beauvais, France). For the 122 enumeration of the anaerobic mesophilic microflora agar Schaedler (Biokar Diagnostics, 123 Beauvais, France) with defibrinated sheep blood at $5 \%$ (E\&O Laboratories Ltd., UK) was 124 used. Aerobic TVC were cultivated for $72 \mathrm{~h}$ at $30 \pm 1{ }^{\circ} \mathrm{C}$ and anaerobic TVC - at $37 \pm 1{ }^{\circ} \mathrm{C}$ 125 for $72 \mathrm{~h}$ at anaerobic conditions, assured by the GENbag anaer system (BioMerieux SA, 126 Marcy l'Etoile, France). The different morphologies obtained on the TVC agar plates were 127 further isolated on Tryptone Soy Agar (TSA) (Biokar Diagnostics, Beauvais, France) and 128 Nutrient Agar at $2 \%$ (Biokar Diagnostics, Beauvais, France) for Gram staining and 129 identification.

\section{2.2.2. Definition of the Total Enterobacterial Counts}

131 For the enumeration of the total enterobacterial counts the samples from the same batch and

132 brand were opened, mixed and $25 \mathrm{~g}$ per product were weighted in TEMPO ${ }^{\circledR}$ bags 133 (BioMerieux SA, Marcy l'Etoile, France) in aseptic conditions. These were diluted with 225 $134 \mathrm{ml}$ of sterile Tryptone-Salt broth (Biokar Diagnostics, Beauvais, France) and homogenized 135 during $30 \mathrm{sec}$. in our Laboratory Blender Stomacher 400. Further on this material was used 136 for the inoculation of TEMPO ${ }^{\circledR} \mathrm{EB}$ cards (BioMerieux SA, Marcy l'Etoile, France) in the 137 TEMPO $^{\circledR}$ preparation station as according to the manufacturer's instructions. The cards were 138 incubated during $24 \mathrm{~h}$ at $35 \pm 1{ }^{\circ} \mathrm{C}$ in an incubator and then results were read and interpreted 139 with the TEMPO $^{\circledR}$ Reader station and associated software. This method represents a 140 miniaturized MPN assay.

\subsection{Identification of the isolates}

142 Gram staining was done for all pure enterobacterial and mesophillic isolates. Catalase 143 reaction was tested for the TVC isolates on single colony material by treatment with a 


\subsubsection{Identification by $A P I^{\circledR}$ tests}

Fresh $(24 \mathrm{~h})$ colonies of all enterobacterial isolates were homogenized in sterile distilled water and inoculated into API 20E galleries (BioMerieux SA, Marcy l'Etoile, France) following the instructions of the manufacturer. For some TVC isolates identification was done with the API 20A (Anaerobes) and API 50CHB (Bacillus) galleries, where applicable, as in accordance with the list of genera/species included in the identification range of the corresponding type of gallery. Staphylococcal isolates were identified by the API Staph test. Results were expressed in percentages of probability for the identification as according to the ApiWeb software.

\subsubsection{Biolog ${ }^{\circledR}$ Identification}

In parallel, the Biolog ${ }^{\circledR}$ MicroStation system and related software (Biolog, USA) were used for the identification of all enterobacterial and TVC isolates obtained. For the purpose the pure isolates were inoculated on TSA plates prior to Biolog ${ }^{\circledR}$ analysis and incubated at the corresponding conditions for each microbial group. Anaerobiosis was applied in the case of the anaerobic TVC isolates using the GENbag anaer system. The cultures were consequently resuspended in tubes with $10 \mathrm{ml}$ of GN/GP-IF inoculation fluid (Biolog, USA) using the Biolog $^{\circledR}$ turbidity standards and with addition of Biolog ${ }^{\circledR}$ sodium thioglycolate reagent as according to the instructions of the manufacturer. These tubes were used for the inoculation of Biolog ${ }^{\circledR}$ GN2 plates in the case of Gram negative isolates and Biolog ${ }^{\circledR}$ GP2 plates in the case of Gram positive isolates. All plates were inoculated during $24 \mathrm{~h}$ at the cultivation temperatures required $\left(37 \pm 1{ }^{\circ} \mathrm{C}\right.$ for Enterobacteria and $30{ }^{\circ} \mathrm{C}$ for mesophiles) and then results were read in the Biolog ${ }^{\circledR}$ MicroStation plate reader. Interpretation of results was done with the MicroLog3 4.20.04 software and these were expressed in percentages of probability 


\subsection{Shelf life study}

Thirteen commercial products of anchovies in oil were selected at random for the shelf life study in refrigeration, at $4-8^{\circ} \mathrm{C}$, storage conditions adequate for this type of semi-preserves (products stabilized for a limited period by appropriate treatment and sealed in containers,

\subsection{Definition of the histamine content}

Histamine content was measured by HPLC reverse phase chromatography as according to Vieites and colleagues (Ben-Gigirey et al. 1999). $4 \mathrm{~g}$ of homogenized sample were mixed with $20 \mathrm{ml}$ perchloric acid $0.4 \mathrm{M}$, centrifuged for 20 minutes at $4000 \mathrm{rpm}$, and filtered. 1 $\mathrm{ml}$ of the extracted sample was derivatized by adding $200 \mu \mathrm{l} \mathrm{NaOH} 2 \mathrm{~N}, 300 \mu \mathrm{l}$ sodium bicarbonate (saturated solution) and $2 \mathrm{ml}$ dansyl chloride. Tubes were incubated for 45 minutes at $46{ }^{\circ} \mathrm{C}$. Then dansyl chloride residues were removed with $100 \mu \mathrm{l}$ ammonia, centrifuged 5 minutes at $4000 \mathrm{rpm}$, and filtered. Derivatized samples were injected in an HPLC/PDA system (Waters Corporation, MA, USA), using a Nucleosil C18 $5 \mu \mathrm{m}$ reverse phase column and monitored at $\lambda=254 \mathrm{mn}$. Histamine dihydrochloride, mínimum $99 \%$ purity, was purchased by SIGMA-ALDRICH and was used as standard. The detection 


\subsection{Bacteriological analysis of ready-to-eat foods}

\section{Results}

Table 1 presents all food products examined as according to their covering sauce along with the total enterobacterial counts and the corresponding identification of the isolates obtained on selective media (E.E. broth, VRBG) after enrichment. Seven out of the 18 products (approx. $39 \%$ ) did not contain any Enterobacteria, among these four products of anchovies in olive oil, one product of anchovies in vegetable oil and two products of anchovy/ Engraulis spp. snacks. From the rest of the products a total of 30 different Gram-negative, oxidase negative isolates were obtained. Although in most positive samples enterobacteria were present in amounts below the limit of detection of the TEMPO ${ }^{\circledR}$ method $(10 \mathrm{cfu} / \mathrm{g}), 3$ samples showed significant enterobacterial counts $(640,33$ and $21 \mathrm{cfu} / \mathrm{g})$. The sample with highest enterobacterial counts showed highest number of different isolates. The prevailing genera among all isolates were Enterobacter (represented by 8 isolates), Citrobacter (7 isolates), Proteus (3 isolates), Cronobacter (Enterobacter sakazakii) (3 isolates), Hafnia (2 isolates) and Escherichia (2 isolates, among which one identified as E. coli O157:H7). Klebsiella, Serratia, Raoultella and Pantoea were represented by single species each. Citrobacter 
216 positive or negative. In contrast to enterobacterial counts TVC were present in all the

217 samples; however, in 5 products (all anchovies in olive oil, approx. $28 \%$ of the total) only

218 lactic acid bacteria (LAB) were found, namely Pediococcus pentosaceus, a species renowned

219 for its probiotic properties (Osmanagaoglu et al. 2010; Semjonovs \& Zikmanis 2008). In the

rest of the products the contaminating (non-LAB) microflora was more important in quantities. The mesophillic aerobic isolates included several representatives of the coagulase negative Staphylococci (among which Staphylococcus xylosus), Cellulomonas, Rhodococcus, Bacillus and Corynebacterium. Among the anaerobic isolates Desulfomonile tiedjei and Fusobacterium mortiferum were detected. Certain Actinomyces isolates were also found in three of the products as identified by both API and Biolog.

\subsection{Comparison of the methods for identification of the isolates}

Both methods used by us for the identification of the isolates were based on biochemical characterization of each microorganism's carbohydrate metabolism. The Biolog system implies testing for 95 different carbohydrates while the API system is in general more limited in the number of substrates analysed, depending on outreach of each gallery. Therefore, the API system has a more limited database for comparison and certain species are excluded from possible identification as stated in the instruction manuals of the corresponding galleries. We have tried to apply both systems for each isolate, whenever available, in order to reach better identification. In most of the cases the results obtained by the two methods were in good concordance, however, certain discrepancies existed for some of the enterobacterial isolates. In such cases the method providing higher identification probability was selected and included as final identification result in Tables 1 and 2. The identification probabilities given by the Biolog system were very often expressed in similarity index values since no sufficient growth was reached during the maximum incubation period advised by the manufacturer ( 24 


\subsection{Shelf life study}

243

The shelf life study concerning microbiological parameters was realized on thirteen products designated by numbers $4-16$ in Tables 1 and 2 . The initial enterobacterial counts and total number of enterobacterial isolates at time 0 were highest, followed by a prominent decrease after 3 months of storage. At the experimental point of 6 months no enterobacterial counts were found in any of the tested products and only two isolates were obtained after enrichment from the product with highest initial counts $(640 \mathrm{cfu} / \mathrm{g})$ (Fig. 1). No enterobacterial counts /isolates were obtained after 9 months of storage. The most persistent species at refrigeration conditions belonged to the genera Enterobacter and Pantoea (data not shown). Cronobacter (Enterobacter sakazakii) had generally poor viability under the selected conditions. The same reduction in counts was not observed for the TVC. The number of TVC isolates increased for most samples with the increase of the storage period (Fig. 2). The catalase negative staphylococcal isolates (Staph. lentus, Staph. warneri, Staph. saprophyticus, Staph. arlettae, etc.) were the most resistant group at the selected storage conditions. The histamine quantities detected (two values below the detection limit of the method of $10 \mathrm{mg} / \mathrm{kg}$ and one value of 84 $\pm 22 \mathrm{mg} / \mathrm{kg}$ ) in the samples analyzed were below the officially allowed limit for histamine $(200 \mathrm{mg} / \mathrm{kg})$ in products manufactured from fish species associated with high histidine amounts (Commission Regulations No 2073/2005 and No1441/2007).

\section{Discussion}

In this report 18 RTE food products were included, selected and acquired after a preliminary market study. Semi-preserves elaborated with Engraulidae and presented in various types of 
264 covering sauces are highly appreciated by local and international consumers; therefore, their

265

systematic safety control is of great relevance to avoid public health risks. After application of the established ISO procedures for the detection and quantification of indicator and pathogenic microorganisms or alternative validated methods (TEMPO), presence of certain opportunistic or obligate bacterial pathogens, mainly belonging to the Enterobacteriaceae family, was confirmed in $61 \%$ of the foods sampled. Three of the products (17\%) could be considered unsafe for consumption due to their high enterobacterial counts. Thirty different enterobacterial species were isolated from all products analyzed.

Enterobacteriaceae are generally accepted as the primary cause of food spoilage and histamine development in different food products. Species like Citrobacter freundii, found to be one of the predominant enterobacterial isolates in the current research work, together with Morganella morganii, Proteus spp., Enterobacter spp., Klebsiella pneumoniae, Escherichia spp., Hafnia alvei, Raoultella spp. and Serratia spp. have previously been reported as biogenic amine producers in various foods - tuna sandwiches (Kung et al. 2009), packaged and processed meat (Durlu - Özkaya et al. 2001), seafood (Kim et al. 2003), salted mackerel (Tsai et al. 2005), etc., causing indigestion, intoxications and food allergies. Morganella, Citrobacter, Proteus spp., Klebsiella pneumoniae and Hafnia alvei have been known for their important histamine production while Enterobacter amnigenus and Enterobacter cloacae have been shown to produce particularly high amounts of putrescine (Lavizzari et al. 2010). Although we have not isolated any Morganella morganii or Klebsiella pneumoniae species from Engraulis spp. containing RTE foods we have identified several isolates with known histidine decarboxilase activities as Proteus penneri, Proteus mirabilis, Proteus vulgaris, Pantoea spp., Raoultella planticola/ ornithinolytica, Raoultella terrigena and Serratia ficaria. The presence of these microorganisms could suppose certain degree of filet softening, proteolysis, histamine accumulation and spoilage during the storage of the sampled foods. 
483 Table 1. Identification of all enterobacterial isolates obtained from the products

484 containing Engraulis spp.

\begin{tabular}{|c|c|c|c|c|}
\hline \multirow[t]{2}{*}{ Covering sauce } & \multirow{2}{*}{$\begin{array}{l}\text { Total } \\
\text { counts } \\
{[\text { cfu/g] }}\end{array}$} & \multirow[t]{2}{*}{ Identification } & \multicolumn{2}{|c|}{ Method } \\
\hline & & & $\begin{array}{l}\text { API } \\
{[\%]}\end{array}$ & $\begin{array}{l}\text { Biolog ID } \\
{[\%] \text { or SIM } \dagger}\end{array}$ \\
\hline \multirow{7}{*}{ Olive oil } & $\leq 10$ & $\begin{array}{c}\text { Proteus penneri } \\
\text { Proteus mirabilis }\end{array}$ & 99.2 & 0.367 \\
\hline & $\leq 10$ & Citrobacter freundii & 99 & 99 \\
\hline & $\leq 10$ & E. coli 1 & 99 & 99 \\
\hline & $\leq 10$ & $\begin{array}{c}\text { Enterobacter gergoviae } \\
\text { Serratia ficaria }\end{array}$ & 99.8 & $\begin{array}{c}99.8 \\
0.265\end{array}$ \\
\hline & 640 & $\begin{array}{c}\text { Enterobacter aerogenes } \\
\text { Klebsiella oxytoca } \\
\text { Pantoea } \text { spp. } \\
\text { Enterobacter sakazakii } \\
\text { Raoultella terrigena } \\
\end{array}$ & 96 & $\begin{array}{c}99 \\
90.5 \\
0.212 \\
99 \\
\end{array}$ \\
\hline & $\leq 10$ & $\begin{array}{c}\text { E.coli } \mathrm{O} 157: \mathrm{H} 7 \\
\text { Proteus vulgaris }\end{array}$ & 99.9 & 0.328 \\
\hline & $\leq 10$ & Enterobacter hormaechei & & 88 \\
\hline \multirow[t]{2}{*}{ Vegetable oil } & 33 & $\begin{array}{c}\text { Hafnia alvei } \\
\text { Citrobacter freundii } \\
\text { Enterobacter sakazakii }\end{array}$ & $\begin{array}{c}99.6 \\
84 \\
77.7\end{array}$ & \\
\hline & $\leq 10$ & $\begin{array}{c}\text { Citrobacter spp. } \\
\text { Citrobacter braakii } \\
\text { Enterobacter amnigenus }\end{array}$ & $\begin{array}{l}77.8 \\
85.4\end{array}$ & 0.376 \\
\hline \multirow[t]{2}{*}{ Sunflower oil } & $\leq 10$ & $\begin{array}{c}\text { Enterobacter amnigenus } \\
\text { Enterobacter cancerogenus } \\
\text { Hafnia alvei } \\
\text { Raoultella planticolal } \\
\text { ornithinolytica }\end{array}$ & $\begin{array}{c}65.4 \\
\\
85 \\
99.7\end{array}$ & $\begin{array}{l}85 \\
99\end{array}$ \\
\hline & 21 & $\begin{array}{l}\text { Citrobacter freundii } \\
\text { Enterobacter cloacae }\end{array}$ & 99 & 0.136 \\
\hline
\end{tabular}

$485 †$ SIM - Biolog similarity index value (between 0 and 1) provided for each identification by the Biolog system.

486 Good identification by this system is normally considered for SIM index values above 0.3. 
483 Table 1. Identification of all enterobacterial isolates obtained from the products

484 containing Engraulis spp.

\begin{tabular}{|c|c|c|c|c|}
\hline \multirow[t]{2}{*}{ Covering sauce } & \multirow{2}{*}{$\begin{array}{l}\text { Total } \\
\text { counts } \\
{[\text { cfu/g] }}\end{array}$} & \multirow[t]{2}{*}{ Identification } & \multicolumn{2}{|c|}{ Method } \\
\hline & & & $\begin{array}{l}\text { API } \\
{[\%]}\end{array}$ & $\begin{array}{l}\text { Biolog ID } \\
{[\%] \text { or SIM } \dagger}\end{array}$ \\
\hline \multirow{7}{*}{ Olive oil } & $\leq 10$ & $\begin{array}{c}\text { Proteus penneri } \\
\text { Proteus mirabilis }\end{array}$ & 99.2 & 0.367 \\
\hline & $\leq 10$ & Citrobacter freundii & 99 & 99 \\
\hline & $\leq 10$ & E. coli 1 & 99 & 99 \\
\hline & $\leq 10$ & $\begin{array}{c}\text { Enterobacter gergoviae } \\
\text { Serratia ficaria }\end{array}$ & 99.8 & $\begin{array}{c}99.8 \\
0.265\end{array}$ \\
\hline & 640 & $\begin{array}{c}\text { Enterobacter aerogenes } \\
\text { Klebsiella oxytoca } \\
\text { Pantoea } \text { spp. } \\
\text { Enterobacter sakazakii } \\
\text { Raoultella terrigena } \\
\end{array}$ & 96 & $\begin{array}{c}99 \\
90.5 \\
0.212 \\
99 \\
\end{array}$ \\
\hline & $\leq 10$ & $\begin{array}{c}\text { E.coli } \mathrm{O} 157: \mathrm{H} 7 \\
\text { Proteus vulgaris }\end{array}$ & 99.9 & 0.328 \\
\hline & $\leq 10$ & Enterobacter hormaechei & & 88 \\
\hline \multirow[t]{2}{*}{ Vegetable oil } & 33 & $\begin{array}{c}\text { Hafnia alvei } \\
\text { Citrobacter freundii } \\
\text { Enterobacter sakazakii }\end{array}$ & $\begin{array}{c}99.6 \\
84 \\
77.7\end{array}$ & \\
\hline & $\leq 10$ & $\begin{array}{c}\text { Citrobacter spp. } \\
\text { Citrobacter braakii } \\
\text { Enterobacter amnigenus }\end{array}$ & $\begin{array}{l}77.8 \\
85.4\end{array}$ & 0.376 \\
\hline \multirow[t]{2}{*}{ Sunflower oil } & $\leq 10$ & $\begin{array}{c}\text { Enterobacter amnigenus } \\
\text { Enterobacter cancerogenus } \\
\text { Hafnia alvei } \\
\text { Raoultella planticolal } \\
\text { ornithinolytica }\end{array}$ & $\begin{array}{c}65.4 \\
\\
85 \\
99.7\end{array}$ & $\begin{array}{l}85 \\
99\end{array}$ \\
\hline & 21 & $\begin{array}{l}\text { Citrobacter freundii } \\
\text { Enterobacter cloacae }\end{array}$ & 99 & 0.136 \\
\hline
\end{tabular}

$485 †$ SIM - Biolog similarity index value (between 0 and 1) provided for each identification by the Biolog system.

486 Good identification by this system is normally considered for SIM index values above 0.3. 
Table 2. Identification of the total viable count (TVC) isolates from the ready-toeat products analyzed.

\begin{tabular}{|c|c|c|c|c|}
\hline \multirow[t]{2}{*}{ Covering sauce } & \multicolumn{2}{|c|}{ Identification } & \multicolumn{2}{|c|}{ Method } \\
\hline & Aerobes & Anaerobes & $\begin{array}{l}\text { API } \\
{[\%]}\end{array}$ & $\begin{array}{c}\text { Biolog ID } \\
{[\%] \text { or SIM } \dagger}\end{array}$ \\
\hline \multirow{5}{*}{ Olive oil } & $\begin{array}{l}\text { Pediococcus } \\
\text { pentosaceus }\end{array}$ & ----- & & 99 \\
\hline & $\begin{array}{l}\text { Staphilococcus } \\
\text { epidermidis }\end{array}$ & ---- & & 75 \\
\hline & $\begin{array}{l}\text { Cellulomonas } \\
\text { flavigena }\end{array}$ & ----- & & 0.228 \\
\hline & $\begin{array}{c}\text { Brevibacterium } \\
\text { otitidis } \\
\text { Staphilococcus lentus } \\
\text { Staphilococcus } \\
\text { warneri }\end{array}$ & ---- & 94 & $\begin{array}{l}0.350 \\
0.410\end{array}$ \\
\hline & $\begin{array}{c}\text { Staphilococcus } \\
\text { saprophyticus } \\
\text { Staphilococcus } \\
\text { arlettae }\end{array}$ & ----- & & $\begin{array}{l}0.361 \\
0.789\end{array}$ \\
\hline \multirow{3}{*}{ Vegetable oil } & Staphilococcus lutrae & ----- & & 0.220 \\
\hline & $\begin{array}{c}\text { Staphilococcus } \\
\text { equorum } \\
\text { Bacillus } \\
\text { psychrosaccharolyticu } \\
\text { s } \\
\end{array}$ & $-\cdots$ & & $\begin{array}{l}0.310 \\
0.325\end{array}$ \\
\hline & $\begin{array}{c}\text { Corynebacterium } \\
\text { nitrophilus } \\
\text { Clavibacter agropyri }\end{array}$ & $-\cdots$ & & $\begin{array}{c}0.440 \\
90\end{array}$ \\
\hline \multirow[t]{2}{*}{ Sunflower oil } & $\begin{array}{l}\text { Cellulomonas } \\
\text { flavigena } \\
\text { Rhodococcus } \\
\text { rhodochrous }\end{array}$ & ---- & & $\begin{array}{l}0.370 \\
0.337\end{array}$ \\
\hline & $\begin{array}{c}\text { Actinomyces } \\
\text { hyovaginalis } \\
\text { Clavibacter agropyri }\end{array}$ & ----- & & $\begin{array}{c}0.280 \\
98\end{array}$ \\
\hline $\begin{array}{l}\text { Snacks of } \\
\text { anchovies }\end{array}$ & $\begin{array}{l}\text { Tsukumurella } \\
\text { inchonensis } \\
\text { Actinomyces } \\
\text { naeslundii } \\
\text { Staphylococcus } \\
\text { xylosus }\end{array}$ & Desulfomonile tiedjei & 60 & $\begin{array}{c}99 \\
98,5 \\
0.182\end{array}$ \\
\hline $\begin{array}{c}\text { Snacks of } \\
\text { Engraulis spp. }\end{array}$ & $\begin{array}{l}\text { Tsukumurella } \\
\text { inchonensis } \\
\text { Actinomyces } \\
\text { naeslundii } \\
\text { Cellulomonas } \\
\text { cellasea }\end{array}$ & $\begin{array}{c}\text { Fusobacterium } \\
\text { mortiferum }\end{array}$ & 90.6 & 0.273 \\
\hline
\end{tabular}


$490 †$ SIM - Biolog similarity index value (between 0 and 1) provided for each identification by the Biolog system.

491 Good identification by this system is normally considered for SIM index values above 0.3.

492 
Fig. 1.

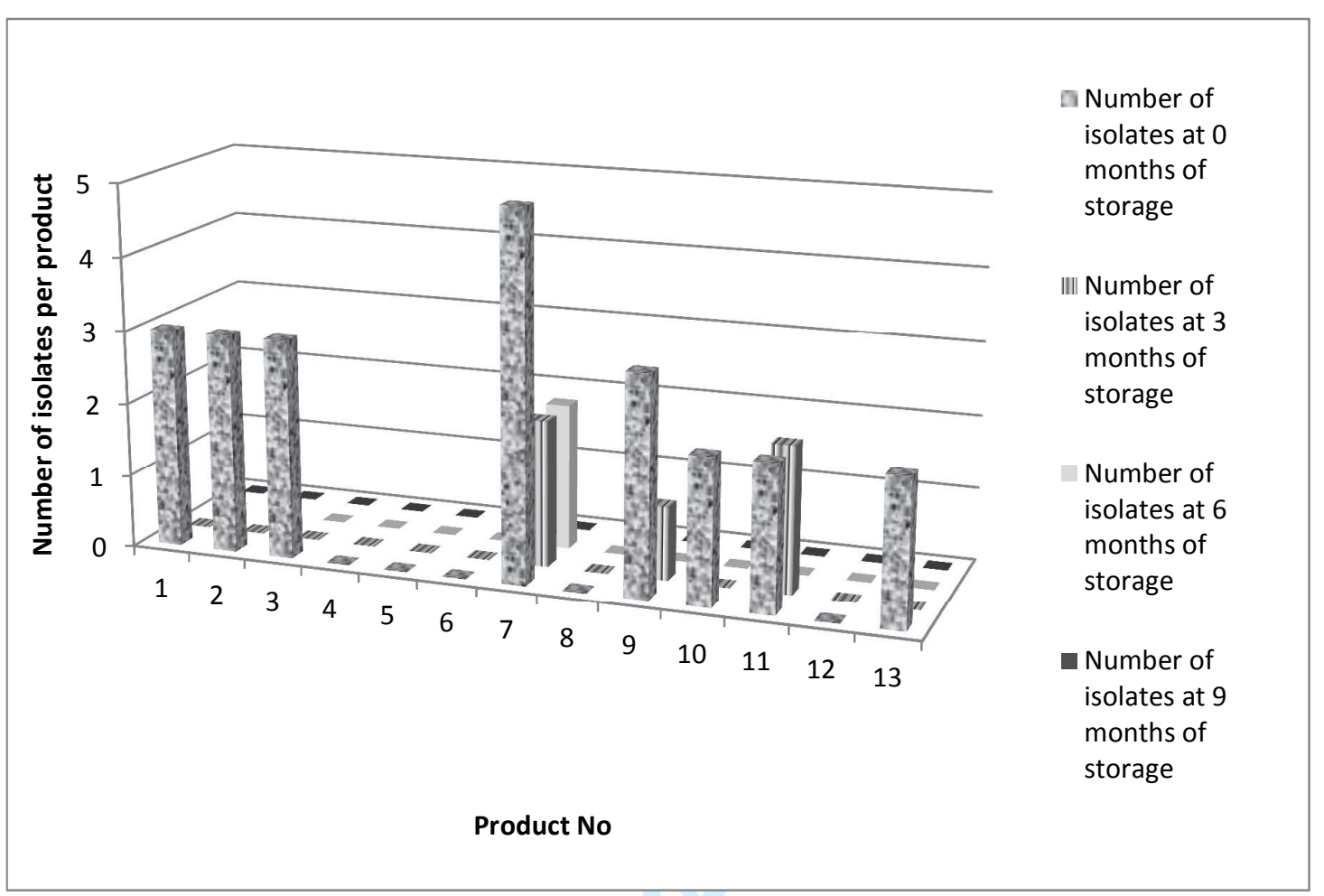


Fig. 2.

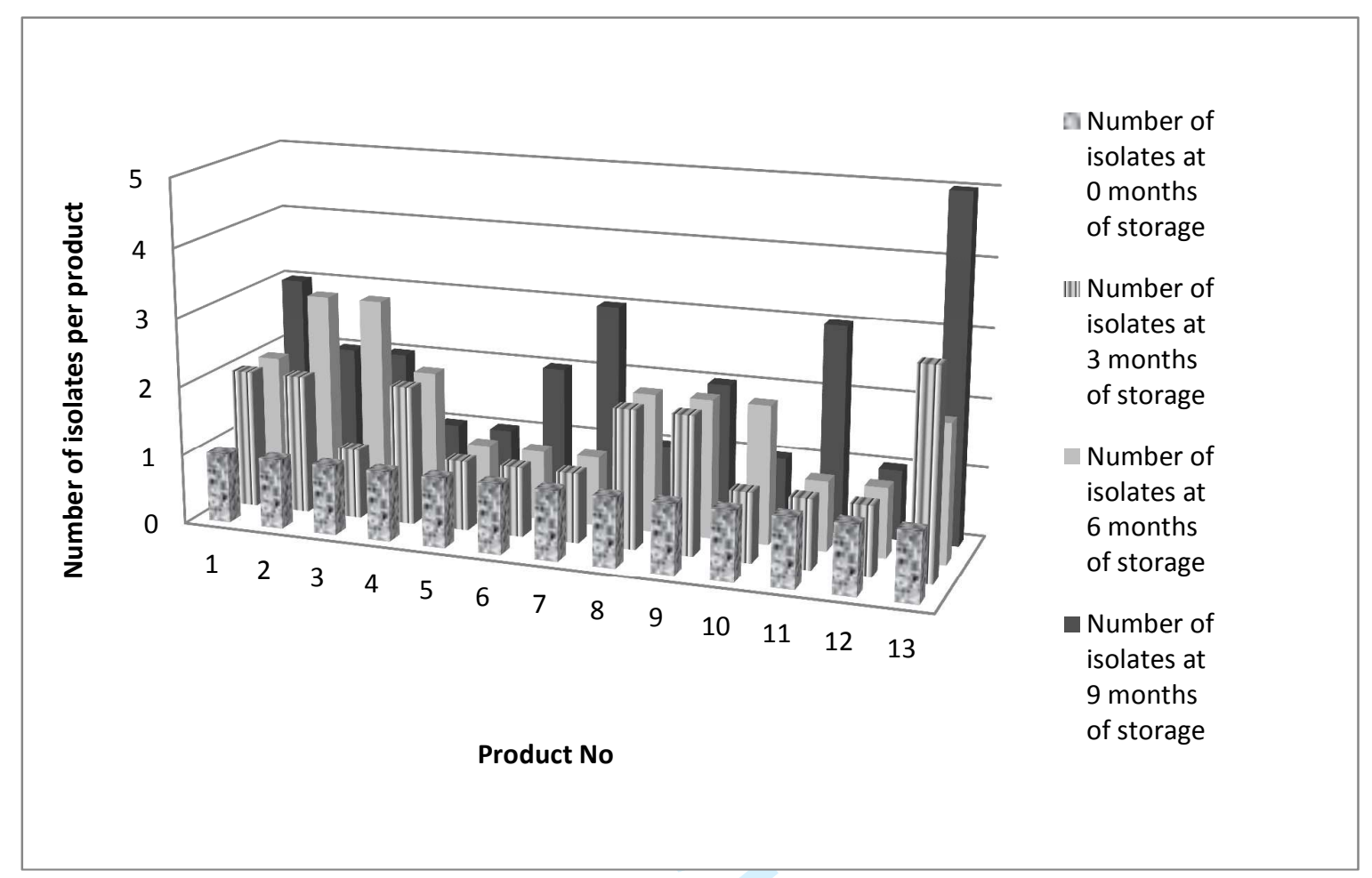


Therefore, the histamine content of the samples with highest enterobacterial counts and

290

291 detected presence of known histamine formers as Hafnia alvei, Citrobacter freundii, Enterobacter aerogenes, E. amnigenus and Raoultella spp. was checked by analytical chromatography. No dependence between the enterobacterial counts and histamine amount in our samples was established, a result previously seen in other research works (RodriguezJerez et al. 1994). Neither were found in the samples analyzed any amounts surpassing the legally fixed histamine levels for this type of foods.

Our results are in good correlation with the enterobacterial species isolated from other RTE and seafood products (Yeboah-Manu et al. 2010; Haryani et al. 2008; Angelidis et al. 2006; Thapa et al. 2006; Fang et al. 2003; Hsu et al. 2009; Rodriguez-Jerez et al. 1994). However, to our knowledge there are no many studies published on the isolation and exhaustive identification of the enterobacterial microflora of traditional Spanish anchovies in oil RTE products.

In the current study we have isolated 8 different Enterobacter spp. isolates, identified as Enterobacter cloacae, E. gergoviae, E. amnigenus, E. aerogenes, E. cancerogenus and E. hormaechei. Enterobacter spp. are generally considered as the sixth most frequent cause of nosocomial infections with antibiotic-resistant strains being reported in literature with increasing frequency (Haryani et al. 2008). Due to the high incidences of antibiotic resistance in E. cloacae it is one of the few bacteria which by official rules have to be monitored in all healthcare facilities in Europe. Several reports exist on bacteremia and bloodstream infections in hospitalized patients caused by E. cloacae, E. aerogenes and Citrobacter freundii (Deal et al. 2007; Chen et al. 2009; Badger et al. 1999). Hafnia alvei, another representative of the Enterobacteriaceae, that has been detected in the RTE foods analyzed in this work (2 isolates), has been shown to be predominantly associated with several intestinal disorders, 
313 gastroenteritis, respiratory tract infections, sepsis, peritonitis, urinary infection and other 314 illnesses (Stock et al. 2005).

315 The medical importance and toxin production by enterohemorrhagic Escherichia coli strains 316 is well known and has already been widely reviewed (Kawasaki et al. 2009; Jothikumar et al. 317 2002). In our study we have reached preliminary identification for two isolates as belonging 318 to E. coli, one of which identified by the database of the Biolog MicroStation system as 319 pathogenic E.coli O157:H7. Although further confirmation of the E. coli identifications is 320 neccessary by the application of the corresponding specific ISO procedures these results are 321 already an indication for posible food-borne illness transmission.

322 In relation to the other bacterial groups studied the staphylococcal isolates were prevailing among all TVC isolates (26 \%, 8 different cultures). No coagulase positive Staphylococci were found in any of the food products analyzed. Nevertheless, some of the coagulase negative staphylococcal isolates obtained on selective and non-selective media (BP-RPF, PCA) represented certain potential hazard to consumer health. Staphylococcus xylosus, isolated from one of the studied products, has been considered by some medical scientists an emerging human pathogen which can cause nosocomial infections and bacteraemia in hospitalized patients (Esper et al. 2000). Among the other mesophillic bacteria identified on the TVC plates Tsukumurella inchonensis is a newly defined species that is related to corynebacteria, Mycobacterium, Nocardia and Rhodococcus. It was originally isolated from blood cultures of different clinical cases (Yassin et al. 1995) and to our knowledge has not previously been reported in food samples. One isolate was identified as Corynebacterium nitrophilus and one as Rhodococcus rhodochrous, belonging to the same group of clinically significant microorganisms. 
336 We have not applied any standard protocols for Listeria monocytogenes detection since the

337

338

339

340

341

342

343

344

345

346

347

348

349

350

351

352

353

354

355

356

357

358

359

growth of this pathogen was not supported at the low humidity conditions (35\%, water activity Aw of 0.657$)$ and high content of chlorinated compounds (12.5\%) experimentally defined in the analyzed products (data not shown).

In summary, during the 9-month shelf life study, intended to determine the possible qualitative and quantitative changes in the discovered bacterial microflora at storage conditions recommended by the manufacturers of the selected RTE foods on their respective packaging (approx. 1 year at temperatures between 5 and $12{ }^{\circ} \mathrm{C}$ ), we have seen that most of the enterobacterial species present were still viable over a three month storage period with only two viable isolates obtained after 6 months of storage. This tendency was further confirmed at the last point of 9 months of storage when absolutely no counts and no isolates were obtained after the two-step enrichment procedure on selective media. We considered that the observed decline in enterobacterial numbers and loss of viability might be due to the preserving effect of the salt (high content of chlorinated compounds in the samples) and the plant oil dressing. The antimicrobial effect of plant oils has been known for long and the bactericidal action of some essential plant oils on enterobacterial pathogens (E.coli and various Salmonella species) has previously been demonstrated (Peñalver et al. 2005).

Thus, it has been demonstrated that these traditional RTE foods, elaborated with Engraulis sp. and preserved under cold storage in salt and oil dressing, are at high risk of being contaminated by enterobacteria and staphylococci. Due to recent legislative changes introduced at EU level the manufacturers need to obtain detailed information on possible microbiological risks in their production lines and to design additional control actions in order to assure the supply of safe and high quality products to the market. 
361

362

363

364

365

366

367

368

369

370

371

372

373

374

375

376

377

378

379

380

381

1. ANGELIDIS, A.S., CHRONIS, E.N., PAPAGEORGIU, D.K., KAZAKIS, I.I., ARSENOUGLOU, K.C. and STATOPOUlOS, G.A. 2006. Non-lactic acid, contaminating microbial flora in ready-to-eat foods: A potential food-quality index. Food Microbiology 23: 95-100.

2. BADGER, J.D., STINS, M.F. and KIM, K.S. 1999. Citrobacter freundii invades and replicates in human brain microvascular endothelial cells. Infection and Immunity 67: $4208-4215$.

3. BAUMGARTNER, A., GRAND, M., LINIGER, M. and IVERSEN, C. 2009. Detection and frequency of Cronobacter spp. (Enterobacter sakazakii) in different categories of ready-to-eat foods other than infant formula. International Journal of Food Microbiology 136: 189-192.

4. BEN-GIGIREY, B., VIEITES-BAPTISTA-DE-SOUSA, J.M., VILLA, T.G. and BARROS-VELAZQUEZ, J. 1999. Histamine and cadaverine production by bacteria isolated from fresh and frozen albacore (Thunnus alalunga). Journal of Food Protection 62: 933-939.

5. CHEN, K.J., YANG, K.J., SUN, C.C. and YEUNG, L. 2009. Traumatic endophtalamitis caused by Enterococcus raffinosus and Enterobacter gergoviae. Journal of Medical Microbiology 58: 526-528.

6. The Commission of the European Communities (CEC) 2005. Commission Regulation (EC) No 2073/2005 on microbiological criteria for foodstuffs (text with EEA relevance). Official Journal of the European Union L338: 1 - 26. 
7. The Commission of the European Communities (CEC) 2007. Commission Regulation (EC) No 1441/2007 amending Regulation (EC) No 2073/2005 on microbiological

10. ESPER, R. C., MORALES, M. T. and RUIZ, S.S. 2000. Staphylococcus xylosus: Una bacteria emergente. Revista Médica del Hospital General de México 63: 107-111.

11. FANG, T.J., WEI, Q.-K., LIAO, C.-W., HUNG, M.-J. and WANG, T.-H. 2003. Microbiological quality of $18{ }^{\circ} \mathrm{C}$ ready-to-eat food products from Taiwan. International Journal of Food Microbiology 80: 241-250.

12. GOSNEY, M. 2008. Enterobacter sakazakii bacteraemia with multiple splenic abscesses in a 75-year-old woman: a case report. Age and Ageing 37: 236-237.

13. HARYANI, Y., TUNUNG, R., CHAI, L.C., LEE, H.Y., TANG, S.Y. and SON, R. 2008. Characterization of Enterobacter cloacae isolated from street foods. ASEAN Food Journal 15: 57-64. 
14. HSU, H.-H., CHUANG, T.-C., LIN, H.-C., HUANG, Y.-R., LIN, C.-M., KUNG, H.F. and TSAI, Y.-H. 2009. Histamine content and histamine-forming bacteria in dried milkfish (Chanos chanos) products. Food Chemistry 114: 933-938.

15. ISO, 2003. Microbiology of food and animal feeding stuffs -- Horizontal method for the enumeration of microorganisms -- Colony-count technique at 30 degrees $\mathrm{C}$ (ISO 4833:2003).

16. ISO, 2003. Microbiology of food and animal feeding stuffs -- Horizontal method for the enumeration of coagulase-positive staphylococci (Staphylococcus aureus and other species) -- Part 3: Detection and MPN technique for low numbers (ISO 6888-3:2003).

17. ISO, 2004. Microbiology of foods and animal feeding stuffs - Horizontal methods for the detection and enumeration of Enterobacteriaceae - Part 1: Detection and enumeration by MPN technique with pre-enrichment (ISO 21528-1:2004).

18. ISO, 2007. Microbiology of food and animal feeding stuffs - General requirements and guidance for microbiological examinations (ISO 7218:2007).

19. JOTHIKUMAR, N. and GRIFFITS, M.W. 2002. Rapid Detection of Escherichia coli O157:H7 with Multiplex Real-Time PCR Assays. Applied Environmental Microbiology 68: 3169-3171.

20. KAWASAKI, S., FRATAMICO, P.M., HORIKOSHI, N., OKADA, Y., TAKESHITA, K., SAMESHIMA, T. and KAWAMOTO, S. 2009. Evaluation of a Multiplex PCR System for Simultaneous Detection of Salmonella spp., Listeria monocytogenes, and Escherichia coli O157:H7 in Foods and in Food Subjected to Freezing. Foodborne Pathogens and Disease 6: 81-89.

21. KIM, S.H., BARROS-VELAZQUEZ, J., BEN-GIGIREY, B., EUN, J.B., JUN, S.H., WEI, C.I. et al. 2003. Identification of the main bacteria contributing to histamine 

460.

22. KUNG, H.-F., WANG, T.-Y., HUANG, Y.-R., LIN, C.-S., WU, W.-S., LIN, C.-M. and TSAI, Y.-H. 2009. Isolation and identification of histamine forming bacteria in tuna sandwiches. Food Control 20: 1013-1017.

23. LAI, K.K. 2001. Enterobacter sakazakii infections among neonates, infants, children and adults. Case reports and a review of the literature. Medicine 80: 113-122.

24. LAVIZZARI, T., BRECCIA, M., BOVER-CID, S., VIDAL-CAROU, M.C. and VECIANA-NOGUES, M.T. 2010. Histamine, cadaverine and putrescine produced in vitro by Enterobacteriaceae and Pseudomonadaceae isolated from spinach. Journal of Food Protection 73: 385-389.

25. OSMANAGAOGLU, O., KIRAN, F. and ATAOGLU, H. 2010. Evaluation of in vitro probiotic potential of Pediococcus pentosaceus OZF isolated from human breast milk. Probiotics and Antimicrobial Proteins 2: 162-174.

26. PEÑAlVER, P., HUERTA, B., BORGE, C., ASTORGA, R., ROMERO, R. and PEREA, A. 2005. Antimicrobial activity of five essential oils against origin strains of the Enterobacteriaceae family. APMIS 113: 1-6.

27. RAY, P., DAS, A., GAUTAM, V., JAIN, N., WIG, J.D. and SHARMA, M. 2007. Postoperative nosocomial Enterobacter sakazakii sepsis. ANZ Journal of Sugrery 77: 915-916.

28. RODRIGUEZ-JEREZ, J., LOPEZ-SABATER, E., HERNANDEZ-HERRERO, M. and MORA-VENTURA, M. 1994. Histamine, putrescine and cadaverine formation in 
spanish semipreserved anchovies as affected by time/temperature. Journal of Food Science 59: 993-997. 
471 35. YASSIN, A.F., RAINEY, F.A., BRZEZINKA, H., BURGHARDT, J., LEE, H.J. and

472 SCHAAL, K.P. 1995. Tsukamurella inchonensis sp. nov. International Journal of $473 \quad$ Systematic Bacteriology 45: 522-527.

474 36. YEBOAH-MANU, D., KPELI, G., AKYEH, M. and BIMI, L. 2010. Bacteriological 475 quality of ready-to-eat foods sold on and around university of Ghana campus. $476 \quad$ Research Journal of Microbiology 5: 130-136.

477 
478 Figure 1. Evolution of the total number of enterobacterial isolates in the products $479 \quad$ analyzed during a 9-month shelf life study.

Figure 2. Evolution of the TVC isolates in the products analyzed during a 9-month 481 shelf life study.

482 
483 Table 1. Identification of all enterobacterial isolates obtained from the products

484 containing Engraulis spp.

\begin{tabular}{|c|c|c|c|c|}
\hline \multirow[t]{2}{*}{ Covering sauce } & \multirow{2}{*}{$\begin{array}{l}\text { Total } \\
\text { counts } \\
{[\text { cfu/g] }}\end{array}$} & \multirow[t]{2}{*}{ Identification } & \multicolumn{2}{|c|}{ Method } \\
\hline & & & $\begin{array}{l}\text { API } \\
{[\%]}\end{array}$ & $\begin{array}{l}\text { Biolog ID } \\
{[\%] \text { or SIM } \dagger}\end{array}$ \\
\hline \multirow{7}{*}{ Olive oil } & $\leq 10$ & $\begin{array}{c}\text { Proteus penneri } \\
\text { Proteus mirabilis }\end{array}$ & 99.2 & 0.367 \\
\hline & $\leq 10$ & Citrobacter freundii & 99 & 99 \\
\hline & $\leq 10$ & E. coli 1 & 99 & 99 \\
\hline & $\leq 10$ & $\begin{array}{c}\text { Enterobacter gergoviae } \\
\text { Serratia ficaria }\end{array}$ & 99.8 & $\begin{array}{c}99.8 \\
0.265\end{array}$ \\
\hline & 640 & $\begin{array}{c}\text { Enterobacter aerogenes } \\
\text { Klebsiella oxytoca } \\
\text { Pantoea } \text { spp. } \\
\text { Enterobacter sakazakii } \\
\text { Raoultella terrigena } \\
\end{array}$ & 96 & $\begin{array}{c}99 \\
90.5 \\
0.212 \\
99 \\
\end{array}$ \\
\hline & $\leq 10$ & $\begin{array}{c}\text { E.coli } \mathrm{O} 157: \mathrm{H} 7 \\
\text { Proteus vulgaris }\end{array}$ & 99.9 & 0.328 \\
\hline & $\leq 10$ & Enterobacter hormaechei & & 88 \\
\hline \multirow[t]{2}{*}{ Vegetable oil } & 33 & $\begin{array}{c}\text { Hafnia alvei } \\
\text { Citrobacter freundii } \\
\text { Enterobacter sakazakii }\end{array}$ & $\begin{array}{c}99.6 \\
84 \\
77.7\end{array}$ & \\
\hline & $\leq 10$ & $\begin{array}{c}\text { Citrobacter spp. } \\
\text { Citrobacter braakii } \\
\text { Enterobacter amnigenus }\end{array}$ & $\begin{array}{l}77.8 \\
85.4\end{array}$ & 0.376 \\
\hline \multirow[t]{2}{*}{ Sunflower oil } & $\leq 10$ & $\begin{array}{c}\text { Enterobacter amnigenus } \\
\text { Enterobacter cancerogenus } \\
\text { Hafnia alvei } \\
\text { Raoultella planticolal } \\
\text { ornithinolytica }\end{array}$ & $\begin{array}{c}65.4 \\
\\
85 \\
99.7\end{array}$ & $\begin{array}{l}85 \\
99\end{array}$ \\
\hline & 21 & $\begin{array}{l}\text { Citrobacter freundii } \\
\text { Enterobacter cloacae }\end{array}$ & 99 & 0.136 \\
\hline
\end{tabular}

$485 †$ SIM - Biolog similarity index value (between 0 and 1) provided for each identification by the Biolog system.

486 Good identification by this system is normally considered for SIM index values above 0.3. 
Table 2. Identification of the total viable count (TVC) isolates from the ready-toeat products analyzed.

\begin{tabular}{|c|c|c|c|c|}
\hline \multirow[t]{2}{*}{ Covering sauce } & \multicolumn{2}{|c|}{ Identification } & \multicolumn{2}{|c|}{ Method } \\
\hline & Aerobes & Anaerobes & $\begin{array}{l}\text { API } \\
{[\%]}\end{array}$ & $\begin{array}{c}\text { Biolog ID } \\
{[\%] \text { or SIM } \dagger}\end{array}$ \\
\hline \multirow{5}{*}{ Olive oil } & $\begin{array}{l}\text { Pediococcus } \\
\text { pentosaceus }\end{array}$ & ----- & & 99 \\
\hline & $\begin{array}{l}\text { Staphilococcus } \\
\text { epidermidis }\end{array}$ & ---- & & 75 \\
\hline & $\begin{array}{l}\text { Cellulomonas } \\
\text { flavigena }\end{array}$ & ----- & & 0.228 \\
\hline & $\begin{array}{c}\text { Brevibacterium } \\
\text { otitidis } \\
\text { Staphilococcus lentus } \\
\text { Staphilococcus } \\
\text { warneri }\end{array}$ & ---- & 94 & $\begin{array}{l}0.350 \\
0.410\end{array}$ \\
\hline & $\begin{array}{c}\text { Staphilococcus } \\
\text { saprophyticus } \\
\text { Staphilococcus } \\
\text { arlettae }\end{array}$ & ----- & & $\begin{array}{l}0.361 \\
0.789\end{array}$ \\
\hline \multirow{3}{*}{ Vegetable oil } & Staphilococcus lutrae & ----- & & 0.220 \\
\hline & $\begin{array}{c}\text { Staphilococcus } \\
\text { equorum } \\
\text { Bacillus } \\
\text { psychrosaccharolyticu } \\
\text { s } \\
\end{array}$ & $-\cdots$ & & $\begin{array}{l}0.310 \\
0.325\end{array}$ \\
\hline & $\begin{array}{c}\text { Corynebacterium } \\
\text { nitrophilus } \\
\text { Clavibacter agropyri }\end{array}$ & $-\cdots$ & & $\begin{array}{c}0.440 \\
90\end{array}$ \\
\hline \multirow[t]{2}{*}{ Sunflower oil } & $\begin{array}{l}\text { Cellulomonas } \\
\text { flavigena } \\
\text { Rhodococcus } \\
\text { rhodochrous }\end{array}$ & ---- & & $\begin{array}{l}0.370 \\
0.337\end{array}$ \\
\hline & $\begin{array}{c}\text { Actinomyces } \\
\text { hyovaginalis } \\
\text { Clavibacter agropyri }\end{array}$ & ----- & & $\begin{array}{c}0.280 \\
98\end{array}$ \\
\hline $\begin{array}{l}\text { Snacks of } \\
\text { anchovies }\end{array}$ & $\begin{array}{l}\text { Tsukumurella } \\
\text { inchonensis } \\
\text { Actinomyces } \\
\text { naeslundii } \\
\text { Staphylococcus } \\
\text { xylosus }\end{array}$ & Desulfomonile tiedjei & 60 & $\begin{array}{c}99 \\
98,5 \\
0.182\end{array}$ \\
\hline $\begin{array}{c}\text { Snacks of } \\
\text { Engraulis spp. }\end{array}$ & $\begin{array}{l}\text { Tsukumurella } \\
\text { inchonensis } \\
\text { Actinomyces } \\
\text { naeslundii } \\
\text { Cellulomonas } \\
\text { cellasea }\end{array}$ & $\begin{array}{c}\text { Fusobacterium } \\
\text { mortiferum }\end{array}$ & 90.6 & 0.273 \\
\hline
\end{tabular}


$490 †$ SIM - Biolog similarity index value (between 0 and 1) provided for each identification by the Biolog system.

491 Good identification by this system is normally considered for SIM index values above 0.3.

492 
Fig. 1.

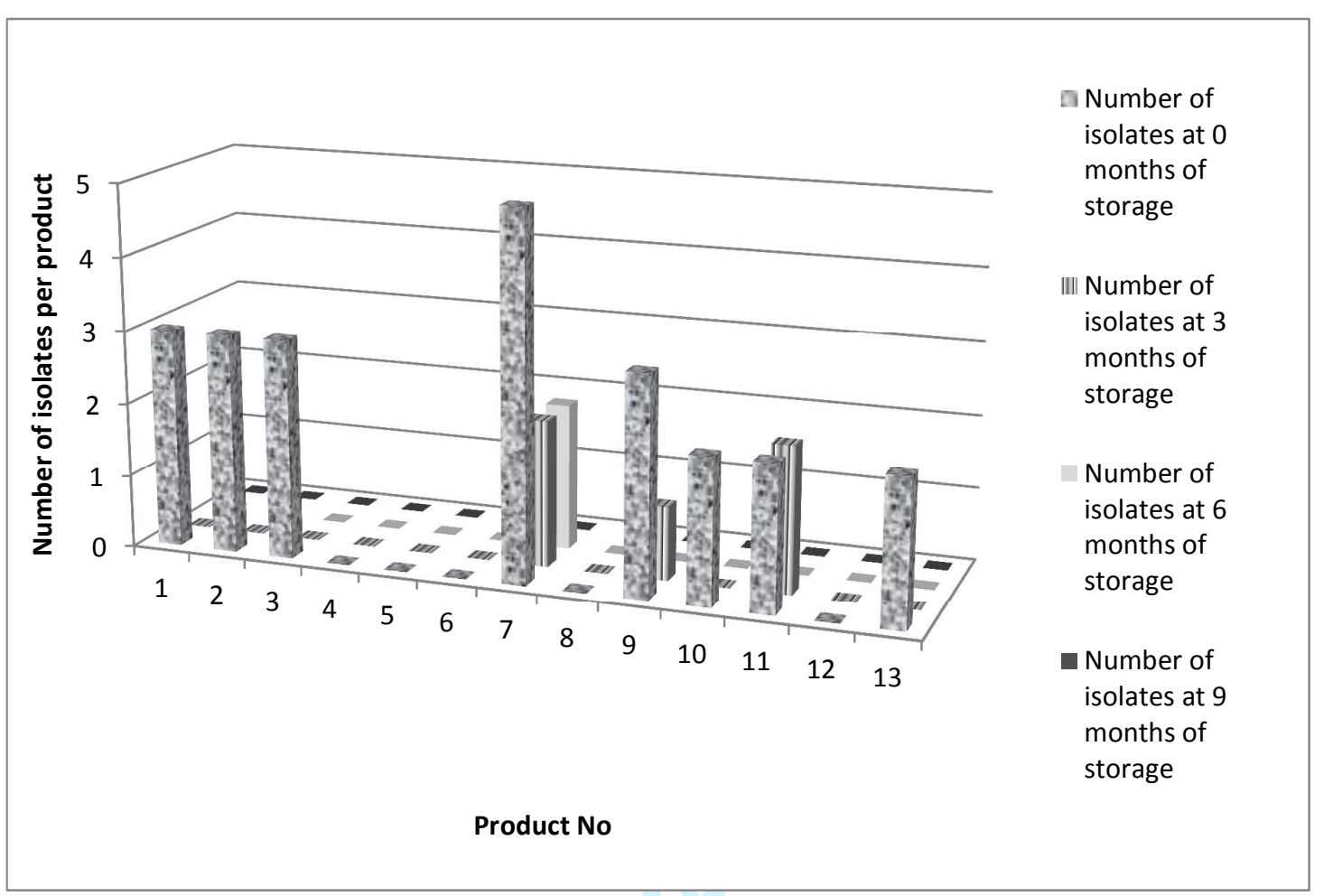


Fig. 2.

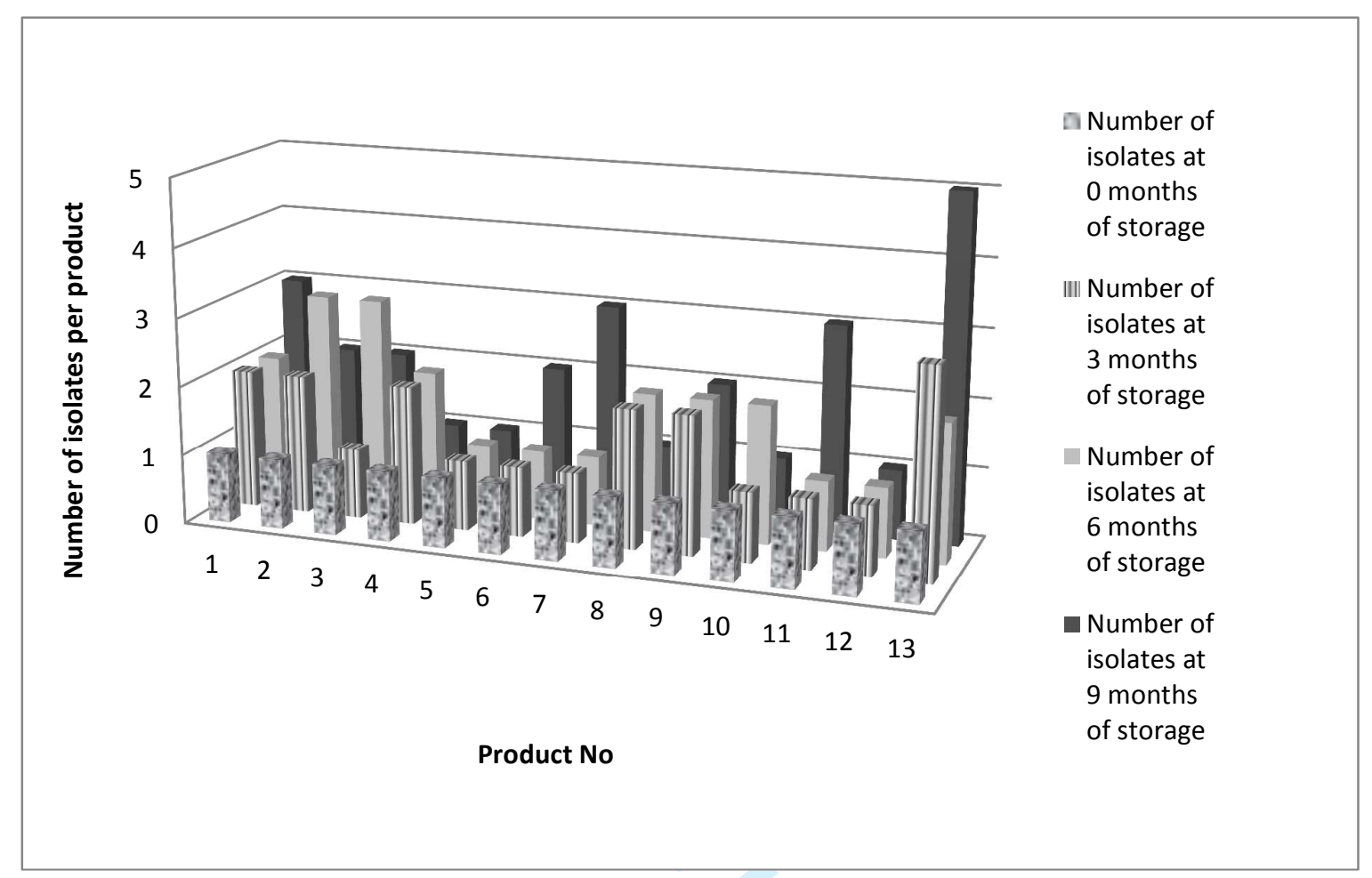

